\title{
Sem ódio e sem favor: formação de juízos técnicos na Secretaria Federal de Controle Interno
}

Leonardo Andrade e Castro

Curso: Mestrado em Sociologia

Data da defesa: 18 de agosto de 2008

Orientador: Prof. Dr. Sadi Dal Rosso

\section{Resumo}

Discute-se a seguinte questão: quais os sentidos das ações administrativas que compõem a auditoria governamental executada pela Secretaria Federal de Controle Interno (integrante da Controladoria-Geral da União, órgão do Poder Executivo federal brasileiro)? Como embasamento conceitual e contextual, são apresentados: elementos de natureza teórica e conceitual sobre a burocracia moderna, com destaque para a obra de Max Weber; conceitos ligados à auditoria governamental; informações relevantes sobre a história dos órgãos do Sistema de Controle Interno do Poder Executivo federal; descrição do funcionamento do trabalho 
de auditoria no âmbito da secretaria em exame; e percepções dos servidores públicos sobre a interferência dos superiores hierárquicos na realização das tarefas e na formação de juízos técnicos. Como resultado, também baseado em entrevistas semiestruturadas realizadas com os servidores e dirigentes, conclui-se que os prováveis sentidos (na acepção weberiana) dos processos e comportamentos examinados são: tradições provenientes da área de auditoria contábil e da atividade judicante; crença, de fundamento ético, em que o papel do trabalho dos servidores é a busca da verdade; consciência ou semiconsciência da relevância dos comportamentos para a construção de um "privilegiamento" positivo de natureza "estamental" para os servidores.

Palavras-chave: estado; burocracia; delegação; controle interno; auditoria. 